\title{
Comparative Study of the Quality of New Potatoes Imported from the Mediterranean Area
}

\author{
Wanda Wadas, Katarzyna Rymuza ${ }^{*}$ \\ 1 Faculty of Natural Sciences, Siedlce University of Natural Sciences and Humanities, ul. Prusa 14, 08-110 Siedlce, \\ Poland \\ * Corresponding author's e-mail: katarzyna.rymuza@uph.edu.pl
}

\begin{abstract}
This paper presents the comparison of the quality of new potatoes imported from the Mediterranean area during the winter-spring period. The study material included the new potatoes imported from Cyprus, Egypt, Israel, Spain and Morocco, purchased in Poland, from the beginning of February to the end of May. The laboratory analyses were performed on a total of 162 potato samples. The dry matter content in the new potatoes imported from Spain and Morocco was higher than in the potatoes originating from Cyprus, Egypt or Israel. The dry matter content in the new potatoes imported from Cyprus, Egypt, and in the majority of new potatoes imported from Israel did not differ significantly. PCA showed that the potatoes which had more dry matter contained more Lascorbic acid but less total sugars. The least L-ascorbic acid content and the lowest protein content were determined in the 'Nicola' potatoes imported from Israel and 'Excellency' tubers imported from Spain. The amounts of L-ascorbic acid and protein in the remaining potato samples tested were at a similar level. The potatoes of the same variety imported from different countries did not differ in terms of L-ascorbic acid content. The 'Maris Peer' tubers imported from Spain had more protein than those originating from Israel. The starch contents in new potatoes imported from Israel and Cyprus were lower compared with the tubers from Egypt, Spain and Morocco. The potatoes which had more starch had higher dry matter contents and more monosaccharides. The highest starch content was determined in the 'Excellency' potatoes, which represent the floury cooking type, imported from Spain or Morocco. The 'Excellency' tubers imported from Morocco had more total sugars and monosaccharides than the potatoes imported from Spain. All of the tested potato varieties had a very low susceptibility to the after-cooking darkening.
\end{abstract}

Keywords: potato, off-season crops, tuber quality, after-cooking darkening

\section{INTRODUCTION}

Early potato is a typical product of Mediterranean countries exported to central and northern European markets (Foti, 1999, Timpanaro, 2003, Ierna, 2010). In the climate of the Mediterranean area, potatoes are mainly grown as an off-season crop growing over the winter-spring months (planting from December to January and harvesting from March to early June) or summerautumn months (planting in early September and harvesting from November to the end of January). Frequently, two crops are grown a year (Timpanaro, 2003, Ierna, 2010, Sgroi et al., 2014). The different climate conditions can have an effect on the tuber quality. The potato tuber quality is influenced by many factors including production area, variety, soil and climate, agronomic practices, harvest time and commercialisation conditions (Mustonen, 2004, Ierna and Melilli, 2014, Trawczyński, 2016, Wegener et al., 2017). The production of two early potato harvests in the Mediterranean area requires the varieties which can adapt to the climatic conditions (Frusciante et al., 1999). Cultivation is carried out over the summer-autumn period and based on the seed-tubers produced locally in the previous spring, and over the winter-spring period when the seed-tubers of foreign varieties from northern European countries like Belgium, Holland or Germany are used (Timpanaro, 2003, Ierna, 2010). 'Spunta' is the most common variety grown in the Mediterranean 
area in both the summer-autumn and winter-spring seasons (Ierna and Mauromicale, 2006, Buono et al., 2009). Potatoes are an excellent source of many bioactive components in the human diet. In our diet, a typical meal of $200 \mathrm{~g}$ of boiled potatoes (at least three medium sized tubers) will contribute $9 \%$ of the Guideline Daily Amount (GDA) of protein, 11\% of carbohydrates, $11 \%$ of dietary fibres, up to $28 \%$ of potassium, $18 \%$ of phosphorus and $15 \%$ of magnesium as well as $47 \%$ of the Recommended Dietary Allowance (RDA) of vitamin C (Haase, 2008, Leszczyński, 2012, Visvanathan et al., 2016). In the early potato production in the Mediterranean area, in both offseason crops, delaying the tuber harvest increased yield and improved the tuber quality by an increase in dry matter content (Ierna, 2010). When the harvest time is delayed, the ascorbic acid content increases in a winter-spring crop, but decreases in a summer-autumn crop. The reverse is observed for nitrates (Ierna, 2010, Ierna and Melilli, 2014). This reversed trend could be caused by a reduction in sunlight intensity and day-length during the potato season (Ierna, 2010, Lee and Kader, 2000). When the harvest date was delayed, phenolics in tubers decreased in both growing seasons (Ierna and Melilli, 2014). Harvest time affects sucrose and reducing sugar content in tubers (Mustonen, 2004). The nutrient content in potatoes depends on a number of factors, with variety being among the most important (Burlingame et al., 2009). New potatoes are harvested at an early growth stage, and have higher concentrations of some phytonutrients than mature tubers (Navarre et al., 2010). In recent years, there has been an increase in demand for new potatoes imported from the Mediterranean area which prompts a need to analyse their nutritional value in the aspect of a healthy diet. The aim of the study was to compare the quality of new potatoes imported from the Mediterranean area during the winter-spring period.

\section{MATERIALS AND METHODS}

\section{Plant material}

The study material included the new potatoes imported from the Mediterranean area. The potatoes were sampled from small local greengrocer's shops and from supermarkets belonging to the major food retail chains in Poland, located in Siedlce. The samples were taken once a week from the beginning of February to the end of May. On each occasion, three samples of each variety of new potato imported from various countries, each weighing approximately $1.5 \mathrm{~kg}$, were purchased. The laboratory analyses were performed on a total of 162 potato samples. In total, six potato varieties imported from five countries were analysed (Table 1). The potatoes purchased in February originated from Cyprus $(\mathrm{n}=15)$, in March and April from Cyprus ( $\mathrm{n}=45)$, Egypt $(\mathrm{n}=18)$ and Israel $(\mathrm{n}=33)$, and in May from Cyprus $(n=27)$, Spain $(n=15)$, Israel $(n=6)$ and Morocco $(n=3)$. Over fifty percent of the examined samples of new potatoes were grown in Cyprus. Only the potatoes imported from Cyprus exhibited the characteristics of early potatoes, consistent with United Nations Economic Commission for Europe Standard FFV-52 (UNECE Standard FFV-52) concerning the marketing and commercial quality control of early and ware potatoes, i.e. they were harvested before they reached complete maturity, marketed immediately after their harvesting, and whose skin could be easily removed without peeling. The other potatoes introduced to the market as new potatoes were harvested after completely mature, had corky skins, and were washed and packed.

\section{Laboratory analysis}

Fresh potatoes were analysed immediately after sampling. The dry matter content was

Table 1. Characteristics of potato varieties (The European Cultivated Potato Database)

\begin{tabular}{|l|c|c|c|c|c|c|}
\hline \multicolumn{1}{|c|}{$\begin{array}{c}\text { Potatoes } \\
\text { imported from }\end{array}$} & Variety & $\begin{array}{c}\text { Country } \\
\text { of origin }\end{array}$ & Maturity & $\begin{array}{c}\text { Tuber shape } \\
\begin{array}{c}\text { Tuber flesh } \\
\text { colour }\end{array}\end{array}$ & $\begin{array}{c}\text { Cooking } \\
\text { type* }\end{array}$ \\
\hline Cyprus, Egypt & Spunta & Netherlands & early & long to oval & light yellow & B \\
\hline Israel & Nicola & German & medium-early & oval to long & light yellow & A \\
\hline Israel, Spain & Maris Peer & United Kingdom & early & oval & cream & light yellow \\
\hline Israel & Orchestra & Netherlands & medium-early & round-oval & cream & AB \\
\hline Israel & Sifra & Netherlands & medium-late & round-oval & round-oval & light yellow \\
\hline Morocco, Spain & Excellency & Netherlands & medium-early & C \\
\hline
\end{tabular}

* Cooking type: A - salad, AB - salad to all-round, B - for general use, C - floury. 
determined with the gravimetric method (Polish Standard PN-EN 12145:2001P), starch with the polarimetric method according to Ewers (Polish Standard PN-EN ISO 10520:2002), total sugars (sucrose, glucose and fructose) and monosaccharides (glucose and fructose) with the LuffSchoorl method (Polish Standard PN-A-79011:1998), total protein with the Kjeldahl method (Polish Standard PN-A-04018:1975/Az3:2002) and L-ascorbic acid with the titration method with 2,6dichlorphenolindophenol according to Tillmans (Polish Standard PN-A-04019:1998). All analyses were performed twice, and the results were expressed as $\mathrm{g}$ or $\mathrm{mg}$ per $1 \mathrm{~kg}$ of fresh weight (FW) of potatoes. The after-cooking darkening of potatoes was also determined. The assessment of potato after-cooking darkening was performed after 10 minutes and 2 hours following boiling in water, using the 9-point Danish scale on which 9 means no darkening and 1 denotes the strongest darkening. The assessment of potato after-cooking darkening was conducted on ten tubers (Roztropowicz 1999). All analyses were carried out at the laboratory of Department of Vegetable Crops, Siedlce University of Natural Sciences and Humanities, Poland.

\section{Statistical analysis}

The results of the study were analysed statistically by means of one-factor ANOVA in which the cultivars from different countries (Spunta from Egypt, Excellency from Spain, Excellency from Morocco, Maris Peer from Spain, Maris Peer from Israel, Nicola from Israel, Orchestra from Israel, and Sifra from Israel) were the experimental factor. The significance of differences was checked using Tukey's test at $\mathrm{p}=0.05$.

A multi-dimensional principal component analysis (PCA) and cluster analysis (Badenes et al., 2000, Lotti et al., 2008) were carried out to compare the quality of new potatoes imported from various countries. As the variables used in the analysis had different units, they were standardised. The number of components considered was selected based on the Kaiser's criterion according to which only the variables with the value greater than 1 are analysed (Iezzoni and Pritts, 1991, Lotti et al., 2008). Such components carry only the most significant information which reflects variation of the objects so they were used in the second part of the analysis - cluster analysis. Euclidean distance was used as a measure of distance between objects and Ward's procedure as an agglomeration method (Nikolic et al., 2010). The intersection point was determined applying the Mojena's rule (Rymuza and Bombik, 2012). Statistical analysis was performed using Statistica 12.0 PL for Windows.

\section{RESULTS AND DISCUSSION}

The dry matter content in the tested new potato samples ranged from 14.4 to $21.36 \%$, depending on the cultivar and country of origin (Table 2). The least dry matter was determined in the 'Maris Peer' and 'Nicola' tubers imported from Israel. The 'Orchestra' and 'Sifra' potatoes imported from the same country contained more dry matter, on average, by $2.12 \%$ and $2.78 \%$, respectively, compared with 'Maris Peer'. The dry matter content in 'Maris Peer' potatoes originating from Spain was higher, on average, by $4.76 \%$ than in the potatoes of the same variety imported from Israel. The 'Excellency' potatoes imported from Spain and Morocco had a similar dry matter content, the same finding being detected for the 'Spunta' potatoes imported from Cyprus and Egypt. In general, the dry matter content in the new potatoes imported from Cyprus, Egypt and in most tubers imported from Israel did not differ significantly. The dry matter content in the new potatoes imported from Spain and Morocco was higher than in the tubers originating from Cyprus, Egypt or Israel. The new potatoes imported from Spain and Morocco contained a similar amount of dry matter. The dry matter content is one of important characteristics of new potatoes. When tubers are harvested very early, low dry matter content can result in a soggy tuber texture, and decrease the quality of new potatoes (Mustonen, 2004). The dry matter content in potato tubers depends on variety and harvest time. Under the environmental conditions of southern Italy, the dry matter content in the 'Spunta' potatoes amounted to $168 \mathrm{~g} \mathrm{~kg}^{-1} \mathrm{FW}$ at 90 days after planting in the winter-spring crop and $153 \mathrm{~g} \mathrm{~kg}^{-1} \mathrm{FW}$ at 80 days after planting in the summer-autumn crop. Potato harvest delayed by 25-30 days resulted in an increase in the dry matter content of $10 \mathrm{~g} \mathrm{~kg}^{-1} \mathrm{FW}(6 \%)$ in the winter-spring crop, and of $15 \mathrm{~g} \mathrm{~kg} \mathrm{~g}^{-1} \mathrm{FW}(10 \%)$ in the summer-autumn crop (Ierna, 2010). The dry matter content in potato tubers is affected by temperature and day-length during the potato growing season, radiation-use 
efficiency (Kooman et al., 1996) as well as some physiological indicators of plant growth such as assimilation leaf area and the chlorophyll content in leaves (Sawicka et al., 2015). When the potato production in the Mediterranean area takes place over the winter-spring period, potatoes begin to grow when temperatures are relatively low and day-lengths short, and growth continues at increasing temperatures, day-length and irradiation (Ierna, 2010).

The L-ascorbic acid content in the tested potato samples ranged from 115.6 to $133.4 \mathrm{mg} \mathrm{kg}^{-1}$ $\mathrm{FW}$, and protein content from 15.00 to $21.26 \mathrm{~g}$ $\mathrm{kg}^{-1} \mathrm{FW}$ (Table 2). Assuming that daily potato consumption is approximately $150-200 \mathrm{~g}$ (at least three medium-sized tubers), the new potatoes contributed to $22-33 \%$ of the Recommended Dietary Allowance (RDA) of vitamin C and 4-6\% of protein in the daily human diet. The least L-ascorbic acid and the most protein was determined in the 'Nicola' potatoes imported from Israel, and the 'Excellency' imported from Spain. The amount of L-ascorbic acid and protein in the remaining potato samples tested was at a similar level. The potatoes of the same variety, imported from different countries, did not differ in terms of L-ascorbic acid content. The protein content in 'Maris Peer' potatoes imported from Spain was by $5.45 \mathrm{~g} \mathrm{~kg}^{-1}$ FW higher, on average, compared with the tubers of the same variety originating from Israel. The protein content in the 'Maris Peer' tubers imported from Israel was the lowest of all the potato samples tested. Potatoes are an important source of vitamin C (mainly L-ascorbic acid and small amounts of dehydroascorbic acid) in human diet (Love and Pavek, 2008). The vitamin C content insignificantly decreases after cooking of a new potato (Navarre et al., 2010). The ascorbic acid content in the new potatoes from Mediterranean countries depends, besides variety, on the growing season and harvest date. When the harvest time is delayed, the ascorbic acid content increases over the winter-spring months, and decreases during the summer-autumn growing season (Ierna and Melilli 2014). This is related to sunlight intensity and day-length during the period of potato growth. The higher the light intensity during the potato growing season, the greater the ascorbic acid content in plant tissues (Lee and Kader, 2000). The 'Spunta' and 'Nicola' are the most common varieties grown in the Mediterranean area in both the winter-spring months and the summer-autumn season (Timpanaro 2003, Buono et al., 2009). Under the conditions of southern Italy, the ascorbic acid contents in the tubers of these varieties were very similar in both the growing seasons (Ierna and Melilli 2014). In the present study, the L-ascorbic acid content and protein content in the 'Spunta' potatoes imported from Cyprus were similar to the tubers of this variety originating from Egypt. The protein content in potato tuber depends on leaf assimilation area and chlorophyll a content in leaves, while vitamin $\mathrm{C}$ accumulation is only associated with the chlorophyll a content in leaves (Sawicka et al., 2015).

The starch content in the tested potato samples ranged from 71.00 to $142.00 \mathrm{~g} \mathrm{~kg}^{-1} \mathrm{FW}$ depending on cultivar and country of origin (Table 3). The new potatoes imported from Israel and Cyprus were lower in the starch compared with the tubers imported from Egypt, Spain and Morocco. The most starch was determined in the floury 'Excellency' potatoes imported from Spain or Morocco. According to Pereira et al. (2008), starch content is the most stable characteristic of the potato tuber chemical composition. In the present study, the starch content in 'Maris Peer' potatoes imported from Spain was higher, on

Table 2. Dry matter, L-ascorbic acid and protein contents in potato tubers

\begin{tabular}{|c|c|c|c|c|c|}
\hline $\begin{array}{c}\text { Potato } \\
\text { imported from }\end{array}$ & Variety & $\begin{array}{c}\text { Number } \\
\text { of samples }\end{array}$ & $\begin{array}{l}\text { Dry matter } \\
\mathrm{g} \mathrm{kg}^{-1} \mathrm{FW}\end{array}$ & $\begin{array}{l}\text { L-ascorbic acid } \\
\mathrm{mg} \mathrm{kg}^{-1} \mathrm{FW}\end{array}$ & $\begin{array}{c}\text { Protein } \\
\mathrm{g} \mathrm{kg}^{-1} \mathrm{FW}\end{array}$ \\
\hline Cyprus & Spunta & 87 & $170.7 b$ & $120.00 \mathrm{abc}$ & $19.70 a b$ \\
\hline Egypt & Spunta & 18 & $177.4 \mathrm{ab}$ & $124.33 \mathrm{abc}$ & $17.10 \mathrm{ab}$ \\
\hline Spain & Excellency & 9 & $213.6 \mathrm{a}$ & $117.86 \mathrm{c}$ & $21.10 \mathrm{a}$ \\
\hline Spain & Maris Peer & 6 & $191.6 \mathrm{ab}$ & $126.85 \mathrm{a}$ & $20.45 \mathrm{a}$ \\
\hline Israel & Nicola & 15 & $152.4 \mathrm{bc}$ & $115.62 \mathrm{c}$ & $21.26 \mathrm{a}$ \\
\hline Israel & Maris Peer & 6 & $144.0 \mathrm{c}$ & $123.35 \mathrm{abc}$ & $15.00 \mathrm{~b}$ \\
\hline Israel & Orchestra & 9 & $165.2 \mathrm{~b}$ & $133.43 \mathrm{a}$ & $16.63 \mathrm{ab}$ \\
\hline Israel & Sifra & 9 & $171.8 \mathrm{~b}$ & $130.23 \mathrm{ab}$ & $17.70 \mathrm{ab}$ \\
\hline Morocco & Excellency & 3 & $212.6 \mathrm{a}$ & $122.30 \mathrm{abc}$ & $16.00 \mathrm{ab}$ \\
\hline
\end{tabular}

$*$ Means followed by the same letters do not differ significantly at $p=0.05$. 
Table 3. Saccharides in potato tubers $\left(\mathrm{g} \mathrm{kg}^{-1} \mathrm{FW}\right)$

\begin{tabular}{|l|c|c|c|c|c|}
\hline $\begin{array}{c}\text { Potato } \\
\text { imported from }\end{array}$ & Variety & $\begin{array}{c}\text { Number } \\
\text { of samples }\end{array}$ & $\begin{array}{c}\text { Starch } \\
\mathrm{g} \mathrm{kg}^{-1} \mathrm{FW}\end{array}$ & $\begin{array}{c}\text { Total sugars } \\
\mathrm{g} \mathrm{kg}^{-1} \mathrm{FW}\end{array}$ & $\begin{array}{c}\text { Monosaccharides } \\
\mathrm{g} \mathrm{kg}^{-1} \mathrm{FW}\end{array}$ \\
\hline Cyprus & Spunta & 87 & $99.91 \mathrm{bc}$ & $4.99 \mathrm{ab}$ & $3.30 \mathrm{ab}$ \\
\hline Egypt & Spunta & 18 & $111.33 \mathrm{ab}$ & $5.30 \mathrm{a}$ & $3.42 \mathrm{~b}$ \\
\hline Spain & Excellency & 9 & $141.00 \mathrm{a}$ & $4.53 \mathrm{~b}$ & $3.21 \mathrm{ab}$ \\
\hline Spain & Maris Peer & 6 & $113.50 \mathrm{ab}$ & $5.20 \mathrm{ab}$ & $3.56 \mathrm{ab}$ \\
\hline Israel & Nicola & 15 & $86.40 \mathrm{bc}$ & $5.21 \mathrm{ab}$ & $3.36 \mathrm{ab}$ \\
\hline Israel & Maris Peer & 6 & $71.00 \mathrm{c}$ & $5.66 \mathrm{a}$ & $3.75 \mathrm{ab}$ \\
\hline Israel & Orchestra & 9 & $93.33 \mathrm{bc}$ & $5.10 \mathrm{ab}$ & $3.37 \mathrm{ab}$ \\
\hline Israel & Sifra & 9 & $94.67 \mathrm{bc}$ & $4.84 \mathrm{~b}$ & $3.37 \mathrm{ab}$ \\
\hline Morocco & Excellency & 3 & $142.00 \mathrm{a}$ & $5.70 \mathrm{a}$ & $3.87 \mathrm{a}$ \\
\hline
\end{tabular}

* Means followed by the same letters do not differ significantly at $p=0.05$

average, by $42.50 \mathrm{~g} \mathrm{~kg}^{-1} \mathrm{FW}$, than in the tubers of the same variety originating from Israel. The starch content in 'Spunta' potatoes imported from Egypt was only by $11.42 \mathrm{~g} \mathrm{~kg}^{-1} \mathrm{FW}$ higher, on average, than in the tubers of the same variety originating from Cyprus. The potato tuber content of starch is associated with assimilation leaf area, the chlorophyll content in leaves and efficiency of the photosystem in the dark, whereas the total sugars and reducing sugars depend on chlorophyll content in leaves and fluorescence yield (Sawicka et al., 2015). Total sugars in the tested potato samples ranged from 4.43 to $5.70 \mathrm{~g} \mathrm{~kg}^{-1} \mathrm{FW}$, and monosaccharides content fell within the range of 3.21 to $3.87 \mathrm{~g} \mathrm{~kg}^{-1} \mathrm{FW}$. The amounts of total sugars and monosaccharides in the examined potato samples were less different than the starch content (Table 3). The most total sugars and monosaccharides were determined in 'Excellency' tubers imported from Morocco, and 'Maris Peer' potatoes originating from Israel. The amounts of total sugars and monosaccharides in the 'Excellency' potatoes imported from Morocco were, respectively, by 1.17 and $0.66 \mathrm{~g} \mathrm{~kg}^{-1} \mathrm{FW}$ higher, on average, than in the tubers of the same variety grown in Spain, whereas the amounts of these components in the 'Spunta' and 'Maris Peer' potatoes grown in different countries did not differ significantly. Total sugars and monosaccharides in the 'Excellency' tubers imported from Spain were the lowest of all the potato samples analysed. The sugar content of potato tubers is associated with physiological age (Morales-Fernández et al. 2015). The harvest time and variety affected the content of sucrose and reducing sugars in potato tubers. The content of sucrose and reducing sugars, in particular glucose, was lower at the later dates of potato harvest (Mustonen, 2004).

The after-cooking darkening is one of the most important characteristics of potato quality. It is caused by non-enzymatic oxidation reaction of the colourless ferrous-chlorogenic acid compound formed during cooking, exposure to air and coloured ferri-dichlorogenic acid (WangPruski and Nowak, 2004). All of the tested potato varieties were characterised by very low susceptibility to after-cooking darkening, both immediately and two hours after cooking (Table 4). The

Table 4. After-cooking darkening of cooked tubers (9-point Danish scale)

\begin{tabular}{|c|c|c|c|c|}
\hline \multirow{2}{*}{$\begin{array}{c}\text { Potato } \\
\text { imported from }\end{array}$} & \multirow[b]{2}{*}{ Variety } & \multirow{2}{*}{$\begin{array}{c}\text { Number } \\
\text { of samples }\end{array}$} & \multicolumn{2}{|c|}{ Tubers darkening } \\
\hline & & & $\begin{array}{c}10 \text { minutes after } \\
\text { cooking }\end{array}$ & $\begin{array}{c}2 \text { hours } \\
\text { after cooking }\end{array}$ \\
\hline Cyprus & Spunta & 87 & $8.93 \mathrm{a}$ & $8.82 \mathrm{a}$ \\
\hline Egypt & Spunta & 18 & $8.93 \mathrm{a}$ & $8.75 \mathrm{a}$ \\
\hline Spain & Excellency & 9 & $8.73 \mathrm{a}$ & $8.63 \mathrm{a}$ \\
\hline Spain & Maris Peer & 6 & $8.95 \mathrm{a}$ & $8.95 \mathrm{a}$ \\
\hline Israel & Nicola & 15 & $8.82 \mathrm{a}$ & $8.58 \mathrm{a}$ \\
\hline Israel & Maris Peer & 6 & $8.95 \mathrm{a}$ & $8.90 \mathrm{a}$ \\
\hline Israel & Orchestra & 9 & $8.90 \mathrm{a}$ & $8.73 \mathrm{a}$ \\
\hline Israel & Sifra & 9 & $8.93 \mathrm{a}$ & $8.90 \mathrm{a}$ \\
\hline Morocco & Excellency & 3 & 8.90 a & $8.80 \mathrm{a}$ \\
\hline
\end{tabular}

* Means followed by the same letters do not differ significantly at $p=0.05$. 
potato susceptibility to after-cooking darkening is genetically-conditioned but also depends on environmental and agronomic factors. The effect of soil type and management practices on aftercooking darkening is minor compared with the effect of cultivar and climatic conditions (WangPruski et al., 2003, 2007), which was confirmed in the present study. The susceptibility to aftercooking darkening of the 'Spunta' and 'Maris Peer' varieties grown in various countries did not differ significantly. Th e'Excellency' potatoes grown in Spain were slightly more susceptible to discoloration after cooking than the potatoes of the same variety grown in Morocco but the difference was not statistically confirmed. The aftercooking darkening generally increased under drier climatic conditions and in the potatoes grown in the soil which was more susceptible to drought; however, the effects were not found in all cases (Wang-Pruski et al., 2007), which was confirmed in the present study.

Principal component analysis (PCA) demonstrated that the quality of new potatoes was associated with the first three components: PC1, PC2, PC3. The components explained over $88.18 \%$ of the total variance - that is overall multi-dimensional variation of traits (Table 5). The first principal component, accounting for over $46.62 \%$ of total variation, was the most closely correlated with darkening of cooked tubers after 10 minutes following boiling in water (-0.894), protein content $(\mathrm{r}=0.821)$, and darkening of cooked tubers after 2 hours following boiling in water $(-0.768)$. The values of correlation coefficients indicated that the potato varieties rich in protein do not tend to darken after cooking. The second principal component, strongly associated with the content of starch $(r=-0.916)$, dry matter $(r=-0.788)$ and monosaccharides $(\mathrm{r}=0.608)$, explained over $27 \%$ of total variation. The potato varieties which accumulated more starch had higher contents of dry matter and monosaccharides. Similar relations were reported by Ahmadizadeh and Felenja (2011). Additionally, Thybo et al. (2000), Thygensen et al. (2001) and Kreutzmann et al. (2011) reported similar findings and concluded that dry matter and starch contents are the main factors determining the culinary value of potato tubers. The third principal component is mainly the carrier of information about the content of dry matter (0.539), total sugars (-0.569) and Lascorbic acid (0.572). The potatoes which had more dry matter were higher in Lascorbic acid and had less total sugars (Table 5).

As can be seen in Figure 2 which demonstrates the distribution of the tested potato varieties, they differed in terms of the examined characteristics. The PCA scatter plot showed that the potato varieties were characterised by continuous genetic diversity for the most important quality traits. The 'Sifra' and 'Maris Peer' potatoes imported from Israel were characterised by negative values for PC1 and positive values for PC2. These potatoes displayed low after-cooking darkening, and had a low protein, dry matter and starch contents. The 'Maris Peer' tubers imported from Israel and Spain, and 'Spunta' potatoes imported from Egypt had negative intermediate (near zero) values of PC1 and PC2. The 'Excellency' potatoes imported from Morocco and Spain were more diverse. The present study confirmed the substantial differences among the genotypes from different and similar geographic origins, and wide variability was detected for most potato varieties tested.

Table 5. Factor loads, eigenvalues and proportion of the total variance in potato varieties, as explained by the first three principal components

\begin{tabular}{|c|c|c|c|}
\hline Characteristics & PC1 & PC2 & PC3 \\
\hline $\mathrm{X}_{1}$ - Dry mater content $\left(\mathrm{g} \mathrm{kg}^{-1} \mathrm{FW}\right)$ & 0.244 & -0.788 & 0.539 \\
\hline $\mathrm{X}_{2}-$ Starch content $\left(\mathrm{g} \mathrm{kg}^{-1} \mathrm{FW}\right)$ & 0.369 & -0.916 & 0.081 \\
\hline $\mathrm{X}_{3}-$ Total sugars $\left(\mathrm{g} \mathrm{kg}^{-1} \mathrm{FW}\right)$ & -0.719 & -0.355 & -0.569 \\
\hline $\mathrm{X}_{4}-$ Monosaccharides $\left(\mathrm{g} \mathrm{kg}^{-1} \mathrm{FW}\right)$ & -0.752 & -0.608 & -0.172 \\
\hline $\mathrm{X}_{5}-\mathrm{L}$-ascorbic acid content $\left(\mathrm{mg} \mathrm{kg}^{-1} \mathrm{FW}\right)$ & -0.622 & 0.342 & 0.572 \\
\hline $\mathrm{X}_{6}$ - Protein content ( $\mathrm{g} \mathrm{kg}^{-1}$ św.m.) & 0.821 & 0.132 & 0.119 \\
\hline$X_{7}-$ Darkening of cooked tubers after 10 minutes & -0.894 & 0.156 & 0.111 \\
\hline$X_{8}-$ Darkening of cooked tubers after 2 hours & -0.768 & -0.080 & 0.446 \\
\hline Eigenvalue of principal components & 3.729 & 2.121 & 1.203 \\
\hline Explainded proportion of the total variance (\%) & 46.6 & 26.52 & 15.04 \\
\hline Comulative proportion of the total variance $(\%)$ & 46.62 & 73.14 & 88.18 \\
\hline
\end{tabular}




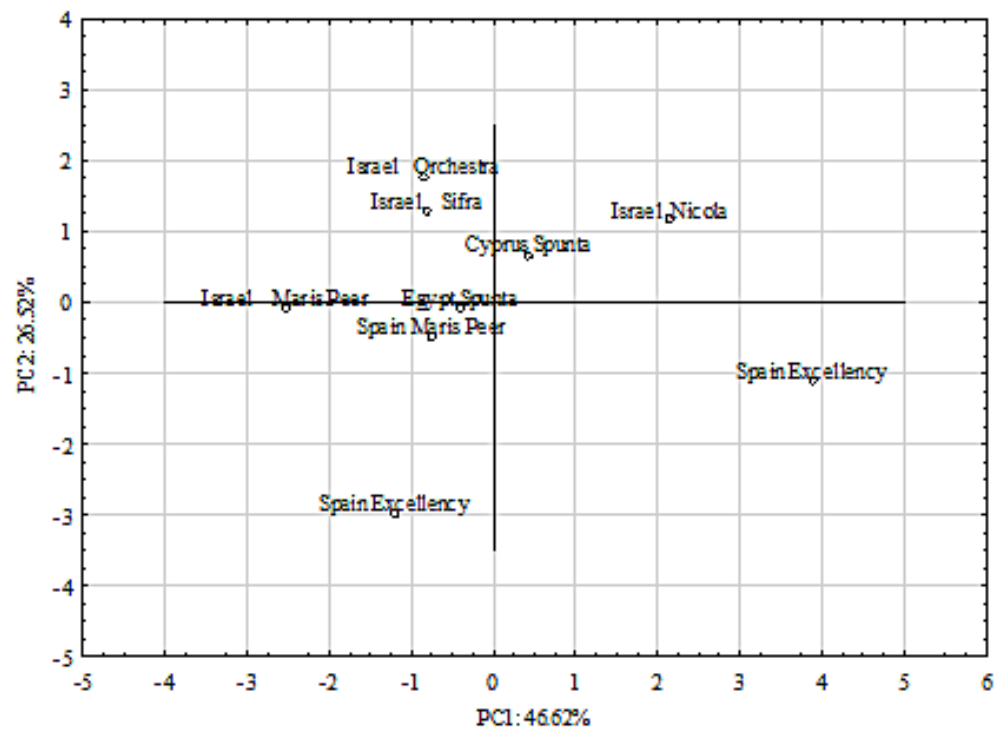

Figure 1. Distribution of 9 potato varieties in terms of 8 traits in the system of two components (PC1, PC2)

Cluster analysis, based on the principal components discussed above, yielded a dendrogram presented in Figure 2. The tested varieties of new potatoes were divided into 3 groups with different properties. Mean values of traits for each group are compiled in Table 6. The first group was made up of five varieties: 'Spunta' imported from Cyprus and Egypt, 'Maris Peer' originating from Spain, and 'Orchestra' and 'Sifra' imported from Israel. Those potatoes had the highest vitamin $\mathrm{C}$ contents and were the least susceptible to after-cooking darkening. The second group included two varieties: 'Maris Peer' imported from Israel and 'Excellency' originating from Morocco. Tubers of the cultivars had the most total sugars and monosaccharides. The third group consisted of the following two potato varieties: 'Excellency' imported from Spain and 'Nicola' grown in Israel. These potatoes had the highest dry matter, starch and protein contents and were the lowest in L-ascorbic acid, total sugars and monosaccharides.

\section{CONCLUSIONS}

The quality of new potatoes imported from the Mediterranean countries and produced during the winter-spring period depended on variety and country of origin. The dry matter content in the new

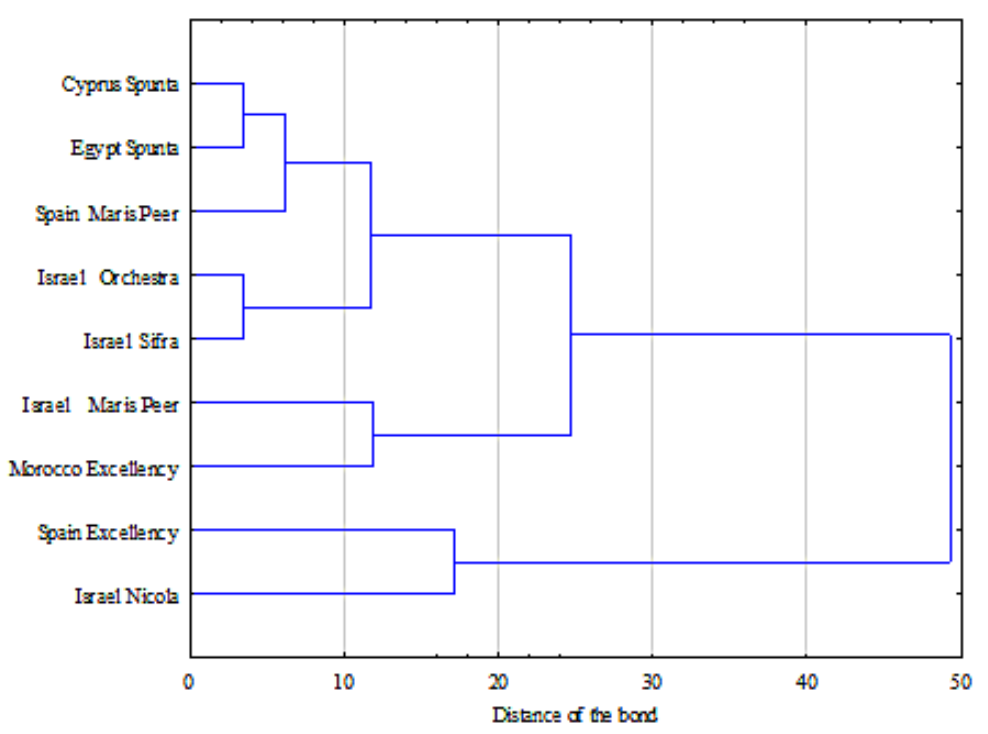

Figure 2. Dendrogram for 9 cultivars obtained for the first three principal components 
Table 6. Means of the examined characteristics of potato varieties divided into three groups based on cluster analysis

\begin{tabular}{|c|c|c|c|}
\hline Characteristics & Group 1 & Group 2 & Group 3 \\
\hline $\mathrm{X}_{1}$ - Dry mater content $\left(\mathrm{g} \mathrm{kg}^{-1} \mathrm{FW}\right)$ & 17.53 & 17.83 & 18.30 \\
\hline $\mathrm{X}_{2}-$ Starch content $\left(\mathrm{g} \mathrm{kg}^{-1} \mathrm{FW}\right)$ & 102.55 & 106.50 & 113.70 \\
\hline$X_{3}-$ Total sugars content $\left(\mathrm{g} \mathrm{kg}^{-1} \mathrm{FW}\right)$ & 5.09 & 5.68 & 4.87 \\
\hline $\mathrm{X}_{4}-$ Monosaccharides content $\left(\mathrm{g} \mathrm{kg}^{-1} \mathrm{FW}\right)$ & 3.40 & 3.81 & 3.24 \\
\hline $\mathrm{X}_{5}-\mathrm{L}$-ascorbic acid content $\left(\mathrm{mg} \mathrm{kg}^{-1} \mathrm{FW}\right)$ & 126.97 & 122.83 & 116.74 \\
\hline $\mathrm{X}_{6}-$ Protein content $\left(\mathrm{g} \mathrm{kg}^{-1} \mathrm{FW}\right)$ & 18.32 & 15.50 & 21.18 \\
\hline$X_{7}-$ Darkening of cooked tubers after 10 minutes & 8.93 & 8.93 & 8.78 \\
\hline$X_{8}-$ Darkening of cooked tubers after 2 hours & 8.83 & 8.85 & 8.61 \\
\hline
\end{tabular}

potatoes imported from Spain and Morocco was higher than in the tubers originating from Cyprus, Egypt or Israel. The dry matter content in the new potatoes imported from Cyprus, Egypt and in the majority of new potatoes imported from Israel did not differ significantly. The potatoes which had more dry matter contained more L-ascorbic acid and less total sugars. The lowest Lascorbic acid content and the highest protein content were determined in the 'Nicola' potatoes imported from Israel, and 'Excellency' originating from Spain. The amount of L-ascorbic acid and protein in the remaining potato samples tested was at a similar level. The potatoes of the same variety imported from different countries did not differ in terms of L-ascorbic acid content. The 'Maris Peer' tubers imported from Spain had more protein than the potatoes grown in Israel. The starch content in the new potatoes imported from Israel and Cyprus was lower than in tubers originating from Egypt, Spain and Morocco. The potatoes which had more starch contained more dry matter and monosaccharides. Floury cooking-type 'Excellency' potatoes imported from Spain or Morocco were the starchiest. 'Excellency' tubers imported from Morocco had more total sugars and monosaccharides than those imported from Spain. All of the tested new potatoes had a very low susceptibility to after cooking darkening. Cluster analysis showed that the 'Spunta' potatoes imported from Cyprus and Egypt, 'Maris Peer' imported from Spain, and 'Orchestra' and 'Sifra' imported from Israel had the most vitamin $\mathrm{C}$ and were the least susceptible to after-cooking darkening. The 'Maris Peer' potatoes imported from Israel, and 'Excellency' imported from Morocco had the most total sugars and monosaccharides, whereas the 'Excellency' tubers imported from Spain, and 'Nicola' imported from Israel had the most dry matter, starch and protein and were the lowest in L-ascorbic acid, total sugars and monosaccharides.

\section{REFERENCES}

1. Ahmadizadeh M., Felenji H., 2011. Evaluating diversity among potato cultivars using agro-morphological and yield components in fall cultivation of Jiroft area. American-Eurasin Journal of Agricultural and Environmental Science, 11(5), 655-662.

2. Badenes M.L., Martinez-Calvo J., Llacer G. (1998). Analysis of apricot germplasm from the European ecogeogaphical group. Euphytica, 102, 93-99.

3. Buono V., Paradis A., Serio F., Gonnella M., De Gara L., Santamaria P. (2009). Tuber quality and nutritional components of "early" potato subjected to chemical haulm desiccation. Journal of Food Composition and Analysis, 22(6), 556-562. DOI: https://doi.org/10.1016/j.jfca.2009.01.001

4. Burlingame B., Mouillé B., Charrondiére R. (2009). Nutrients, bioactive non-nutrients and antinutrients in potatoes. Journal of Food Composition and Analysis, 22(6), 494-502. DOI: https://doi. org/10.1016/j.jfca.2009.09.001

5. Foti S. (1999). Early potatoes in Italy with particular reference to Sicily. Potato Research, 42(2): 229240. DOI: https://doi.org/10.1007/bf02357855

6. Frusciante L., Barone A., Carputo D., Ranalli P. (1999). Breeding and physiological aspects of potato cultivation in the Mediterranean region. Potato Research, 42 (2), 265-277. DOI: https://doi. org/10.1007/bf02357857

7. Haase N.U. (2008). Healthy aspect of potatoes as part of the human diet. Potato Research, 51(3-4): 239-258. DOI: https://doi.org/10.1007/s11540008-9111-4

8. Ierna A. (2010). Tuber yield and quality characteristics of potatoes for off-season crops in a Mediterranean environment. Journal of the Science of Food and Agriculture, 90 (1), 8590. DOI: https:// doi.org/10.1002/jsfa.3786

9. Ierna A., Mauromicale G. 2006. Physiological and growth response to moderate water deficit of offseason potatoes in a Mediterranean environment. Agricultural Water Management, 82 (1-2), 193-209. DOI: https://doi.org/10.1016/j.agwat.2005.05.005 
10. Ierna A., Melilli M.G. (2014). Ascorbic acid and total phenolic content in early potatoes as effect by growing season, genotype and harvest time. Acta Horticulturae (ISHS), 1040, 133-141. DOI: https:// doi.org/10.17660/actahortic.2014.1040.17

11. Iezzoni A.F., Pritts M.P. (1991). Application of principal components analysis to horticultural research. Horticultural Science, 26(4), 334-338.

12. Kooman P.L., Fahem M., Tegera P., Haverkot A.J. (1996). Effect of climate on different potato genotypes. 1. Radiation interception, total and tuber dry matter production. European Journal of Agronomy, 5(3-4), 193-205. DOI: https://doi.org/10.1016/ s1161-0301(96)02031-x

13. Kreutzmann S., Bassompierre M., Kistrup A., Buch L., Engelsen S.B., 2011. Exploratory study of potato cultivar differences in sensory and hedonistic applicability tests. Potato Research, 54, 13-28.

14. Lee S.K., Kader A.A. (2000). Preharvest and postharvest factors influencing vitamin $\mathrm{C}$ content of horticultural crops. Postharvest Biology and Technology, 20(3), 207-220. DOI: https://doi. org/10.1016/s0925-5214(00)00133-2

15. Leszczyński W. (2012). Nutrition value of potato and potato products (Review of literature). Biuletyn Instytutu Hodowli i Aklimatyzacji Roślin, 266, 5-20.

16. Lotti C., Marcotrigiano A.R., De Giovanni C., Resta P., Ricciardi A., Zonno V., Fanizza G., Ricciardi L. (2008). Univariate and multivariate analysis performed on bio-agronomical traits of Cucumis melo L. germplasm. Euphytica, 55(4), 511-522. DOI: https://doi.org/10.1007/s10722-007-9257-y

17. Love S.L., Pavek J.J. (2008). Positioning the potato as a primary source of vitamin C. American Journal of Potato Research, 85(4), 277-285. DOI: https://doi.org/10.1007/s12230-008-9030-6

18. Morales-Fernández, S.D., Mora-Aguilar, R., Salinas-Moreno, Y., Rodriguez-Pérez. J.E., ColinasLeón, M.T., Lozoya-Saldaña, H. (2015). Growth, yield and sugar content of potato tubers at different physiological ages. Revista Chapingo, Horticultura, 21(2), 129146.

19. Mustonen L. (2004). Yield formation and quality characteristics of early potatoes during a short growing period. Agricultural and Food Science, 13(4), 390-398. DOI: https://doi. org/10.2137/1239099043633314

20. Navarre D.A., Shakya R., Holden J. (2010). The effect of different cooking methods on phenolics and vitamin $\mathrm{C}$ in developmentally young potato tubers. American Journal of Potato Research, 87(4): 350-359. DOI: https://doi.org/10.1007/s12230010-9141-8

21. Nikolić D., Rakonjac V., Milatović D., Fotirić M. (2010). Multivariate analysis of vineyard peach
[Prunus persica (L.) Batsch.] germplasm collection. Euphytica, 171: 227-234. DOI: https://doi. org/10.1007/s10681-009-0032-3

22. Pereira A.B., Villa Nova N.A., Ramos V.J., Pereira A.R. (2008). Potato potential yield based on climatic elements and cultivar characteristics. Bragantia, 67(2), 327-334. DOI: https://doi.org/10.1590/ s0006-87052008000200008

23. Polish Standard PN-A-04018:1975/Az3:2002. Agricultural food products - Determination of nitrogen by Kjeldahl method and expressing as protein. Polish Committee for Standardization, Warsaw, Poland. (in Polish)

24. Polish Standard PN-A-04019:1998. Food products - Determination of vitamin C content. Polish Committee for Standardization, Warsaw, Poland. (in Polish)

25. Polish Standard PN-A-79011:1998. Dry food mixes - Test methods - Determination of sugar content. Polish Committee for Standardization, Warsaw, Poland. (in Polish)

26. Polish Standard PN-EN 12145:2001P. Fruit and vegetable juices - Determination of total dry matter - Gravimetric method with loss of mass on drying. Polish Committee for Standardization, Warsaw, Poland (in Polish).

27. Polish Standard PN-EN ISO 10520:2002. Native starch - Determination of starch content -Ewers polarimetric method. Polish Committee for Standardization, Warsaw, Poland (in Polish)

28. Roztropowicz S. (ad.) (1999). Methodology of observation, measurements and sampling in agronomic experiments with potato. Instytut Hodowli i Aklinatyzacji Roślin, Jadwisin.

29. Rymuza K., Bombik A. (2012). Comparison of edible potato cultivars by means of some methods of multidimensional analysis. Acta Scientiarum Polonorum, Agricultura, 11(1), 67-77.

30. Sawicka B., Michałek W., Pszczółkowski P. (2015). The relationship of potato tubers chemical composition with selected physiological indicators. Zemdirbyste-Agriculture, 102(1): 41-50. DOI: https:// doi.org/10.13080/z-a.2015.102.005

31. Sgroi F., Di Trapani A.M., Testa R., Tudisca S. (2014). Economic sustainability of early potato production in the Mediterranean area. American Journal of Applied Sciences, 11(9), 1598-1603. DOI: https://doi.org/10.3844/ajassp.2014.1598.1603

32. The European Cultivated Potato database. Available from: http://europotato.org (Accessed 16.01.2018)

33. Thybo AK., Bechmann IE., Martens M., Engelsen SB., 2000. Prediction of sensory texture of cooked potatoes using uniaxial compression, near infrared spectroscopy and low field 1H NMR spectroscopy. 
Journal of Food Science and Technology, 33(2), 103-111.

34. Thygesen LG., Thybo AK., Engelsen SB., 2001. Prediction of sensory texture quality of cooked potatoes from low-field 1H NMR of raw potatoes. The role of chemical constituents. Journal of Food Science and Technology, 34(7), 469-477.

35. Timpanaro G. (2003). Economic aspects and problems of the organic early potato production and market in Italy. Acta Horticulturae, 608, 109-116. DOI: https://doi.org/10.17660/actahortic.2003.608.14

36. Trawczyński C. (2016). The influence of cultivars and weather conditions of vegetation period on the content of some nutritional and anti-nutritional components in potato tubers. Acta Agrophysica, 23(1), 119-129.

37. UNECE Standard FFV-52. Early and ware potatoes. New York, Geneva: United Nations (20011). Available from: http://unece.org/trade/ agr/standard/fresh/ffv-standardse.html (Accessed 16.01.2018)

38. Visvanathan R., Jayathilake C., Jayawardana B.C., Liyanage R. (2016). Health-beneficial properties of potato and compounds of interest. Journal of the Science of Food and Agriculture, 96(15), 48504860. DOI: https://doi.org/10.1002/jsfa.7848

39. Wand-Pruski G., Nowak J. (2004). Potato after cooking darkening. American Journal of Potato Research, 81(1): 7-16. DOI: https://doi.org/10.1007/ bf02853831

40. Wang-Pruski G., Astatkie T., De Jong H., Leclerc Y. (2003). Genetic and environmental interactions affecting potato after-cooking darkening. Acta Horticulturae, 619, 45-52. DOI: https://doi. org/10.17660/actahortic.2003.619.5

41. Wang-Pruski G., Zebarth B.J., Leclerc Y., Arsenault W.J., Botha E.J., Moorehead S., Ronis D. (2007). Effect of soil type and nutrient management on potato after-cooking darkening. American Journal of Potato Research, 84(4), 291-299. DOI: https://doi.org/10.1007/bf02986241

42. Wegener C.B., Jürgens H.U., Jansen G. (2017). Drought stress affects nutritional and bioactive compounds in potatoes (Solanum tuberosum L.) relevant to human health. Functional Foods in Health and Disease, 7(1), 17-35. 